\title{
Flying Saucers and Multiple Realities: A Case Study in Phenomenological Theory
}

\author{
By David Stupple and Abdollah Dashti
}

$\mathbf{T}$ his essay describes a study of the Saucerian Press, a small mail order firm that publishes and sells books to hobbyists interested in flying saucers. The study is part of a series of research projects designed to trace the social history of the flying saucer movement. The Saucerian Press is of particular interest because (1) it has been responsible for the elaboration of folkore ${ }^{1}$ about flying saucers, and (2) it functions as a clearing house of information for flying saucer hobbyists.

The heroes of flying saucer tales are the contactees-the men and women who have claimed contact with extra-terrestrials. First appearing in 1952 , they created a sensation in the American psychic community through their tales of adventure with space people. By 1958 popular interest in the contactees had declined and the movement took a religious turn: small cults developed around certain contactees and a network of magazines and newspapers provided mechanisms for the transmission of the developing folklore.

One contributor to this folklore is Gray Barker, a former high school English teacher who became interested in flying saucers while reporting a monster scare story for Fate magazine. In 1956 Barker published They Knew Too Much About Flying Saucers, a landmark book that introduced the legend of the three Men-In-Black, sinister figures who dress in black, drive black Cadillacs, and harass UFO witnesses who get too close to THE TRUTH. ${ }^{2}$ In 1959 Barker established the Saucerian Press and began publishing literature that elaborated the "MIB" legend and the idea that flying saucers come from inside the Earth. His recent publications have linked flying saucers to a hodgepodge of "New Age" subjects including pyramid energy and natural foods. In his literature Barker presents himself as a believer and has built his circulation by advertising in pro-UFO occult magazines.

Saucerian Press publications provide a bridge that connects its 4,400 customers to "the action." In Gray Barker's Newsletter hobbyists express their opinions about topical controversies and Barker reviews books, announces upcoming conventions, and reveals backstage gossip about well-known "UFOlogists." Many customers have been on the firm's mailing list for years and, as our data show, feel a strong sense of personal 
loyalty to Barker. In this study we explore the demographic characteristics of the Saucerian Press customers, their beliefs, and the extent to which they are integrated into a community of believers.

\section{Theoretical Perspective}

In 1893 William James pointed out that we live in several different mental worlds. ${ }^{3}$ In addition to the "paramount reality" of common sense built up around everyday experiences, there are five mental subuniverses: the world of science, the world of abstract and logical truth, the world of collective illusions and prejudice, the world of supernatural thought, and various worlds of sheer madness and vagary. Each reality is "real" when attended to but the subuniverses are temporary dwelling places and must ultimately terminate into common sense. Literally, James argued, we must return to our senses. What then is the status of deviant belief systems like flying saucer folklore? One possibility is that they can be experienced as mental subuniverses.

Deviant belief systems may also function as paramount realities. This possibility was developed by Alfred Schutz in his study of Cervantes' Don Quixote. ${ }^{4}$ Schutz showed that Don Quixote, far from being a fool, was an ingenious character who, by assuming the intrusion of magical forces (enchanters), transformed discrediting events into confirmations of his world of chivalry: in one case a barber's basin became a golden helmet; in another, windmills became giants. Cervantes also showed that a deviant paramount reality can be shared by more than one person by pointing out that Sancho Panza eventually took over Don Quixote's interpretive scheme.

Burkart Holzner has demonstrated how the idea of collectively shared alternative realities can have broad applicability to modern society. ${ }^{5}$ Introducing the term "epistemic community," Holzer pointed to the worlds of science and religion to demonstrate that communities of people can maintain deviant paramount realities by having commonly agreed upon ways of creating, expanding, and testing knowledge. They must also provide mechanisms to distribute and control (subjective) orientations. Orientations provide: (1) basic frames of reference, and (2) theories that explain experience. Theories, in turn, are validated by appropriate reality tests. The scientific community demands empirical tests but for communities where "things" cannot provide proof, the ultimate test is the mystical experience. Do the customers of the Saucerian Press experience the flying saucer folklore as a subuniverse of experience or as a paramount reality? If the latter is the case we would expect to find that they hold explanatory beliefs, belong to social networks that transmit these beliefs, and experience mystical events that confirm the beliefs.

\section{The Sample and the Method}

To answer this question we sent a questionnaire to each of the 4,400 persons on the Saucerian Press mailing list. A book order solicitation 
accompanied the questionnaire. Barker introduced the questionnaire as a folksy way to "get to know" more about his readers and their interests. Customers were requested to return the questionnaire whether or not they ordered books. About half of the returns included book orders. No follow up request was sent to those who did not return the questionnaire. These procedures, which we saw as necessary to gain access to the respondents, may be responsible for the low return rate.

Although we assumed that most customers would be believers, we wished to isolate the believers from another subculture--amateur researchers who are followers of well-known scientific researchers. Therefore we statistically isolated these two populations. For the believers we counted those respondents who, when asked to recommend a UFO book, chose books by one or both of the two most mentioned contactees: George Adamski and Howard Menger. Adamski, mentioned by fifty-one respondents, started the contactee craze with his reported meeting with a long-haired Venusian on a California desert. Menger, mentioned by twentysix respondents, claimed to be a spaceman himself, and became well known through his frequent appearances on the Long John Nebel Radio Show. Since nine respondents recommended both Adamski and Menger, this left sixty-eight cases for analysis. For the amateur researchers we counted those respondents who chose the two most mentioned scientific researchers: J. Allen Hynek and Jacques Vallee. Hynek, mentioned eighteen times, is a Northwestern University astronomer and the director of the Center for UFO Studies. Vallee, mentioned thirteen times, is a mathematician and astronomer who has made major contributions to the methodology for classifying UFO sightings. Since one respondent mentioned both Hynek and Vallee, this left thirty cases in this group. For the sake of expedience we will hereafter refer to Adamski and Menger as "The Mystics" and to Hynek and Vallee as "The Scientists."

We use the concept epistemic community as an ideal type against which we compare our data. ${ }^{6}$ Information on occupation, marital status, sex and age provide a description of the social location of the respondents. To answer the question about social networks we asked "Do you belong to a group that studies UFOs?" and "If you had to recommend one book on UFOs what would it be?"

The respondents' subjective orientations were measured by another set of questions. To map their frame of reference we provided a list of occult topics and asked them to place a checkmark next to those that they would "like to read more books about." To explore their explanatory beliefs we asked "Is there a government conspiracy to suppress the real truth about flying saucers?" and "Is there a Silence Group (Men-In-Black) that harasses UFO witnesses?" To determine whether they had mystical experiences that would function as reality tests we asked "Have you had any unusual psychic experiences, and if so, can you describe them?"

\section{Analysis}

Table I provides an overview of the social location of the readership. 
Middle class, male, and older persons are somewhat overrepresented. Respondents tend to be older than the general population probably because the heyday of the contactees was in the 1950s and many Saucerian Press customers first became involved in the movement at that time. Note that the followers of the scientists are considerably younger than the other respondents and, judging by their occupation or student status, presumably are better educated. Considering these factors and the factor of marital status, there is reason to believe that Saucerian Press readers are reasonably well integrated into society. ${ }^{\text {? }}$

Table II provides information on the degree of integration within the flying saucer subculture. Here we see that interest in the contactees provides a basis for cohesion. While most people's awareness of the flying saucer mystery is formed by television and popular paperbacks, Saucerian Press customers recommended books that are virtually unknown outside hobbyists'. The small number of occult and religious books recommended suggests that the social organization of flying saucer hobbyists is functionally independent of the occult social world from which it was born.

Only twelve percent of the Saucerian Press readership belongs to occult and religous groups that "study" UFOs and only ten percent belong to scientific groups that research the subject. There are substantial differences between the two subgroups, as twenty-two percent of the followers of the mystics belong to occult and religious groups that study flying saucers while no follower of the scientists belongs to such a group. This situation is reversed for membership scientific groups: forty-one percent of the followers of the scientists belong while only five percent of the followers of the mystics belong.

Membership in occult and religious groups in fragmented into fifty-one groups, only three of which are mentioned by as many as three persons. The largest contactee groups in the United States-The Mark Age Foundation (Miami Beach), The Aetherius Society (Los Angeles), and Understanding Unlimited (Tonopah, Arizona)-receive no mention. Membership in civilian research groups the pattern for reverses: three groups receive the majority of mentions. The National Investigations Committee on Aerial Phenomena (Washington D.C.) is mentioned twenty-three times, The Aerial Phenomena Research Organization (Tuscon) is mentioned seventeen times, and the Mutual UFO Network (Sequin, Texas) is mentioned eight times.

The Saucerian Press readership is a collectivity of people who share a common interest in the folklore that has developed around flying saucers. The majority do not belong to groups that share this collective interest. Forty-nine percent subscribe to UFO magazines. The typical hobbyist belongs to a mass rather than a public. ${ }^{8}$ Presumably his/her interests and ideas are shaped by persons who control the subculture media. 
TABLE I

Selected Demographic Information by Total Survey Population, Those Who Recommend Mystics, and Those Who Recommend Scientists

Total Population Recommends Mystics Recommends Scientists

\begin{tabular}{|c|c|c|c|c|c|c|}
\hline Occupation & $\mathbf{N}$ & $\%$ & $\mathbf{N}$ & $\%$ & $\mathbf{N}$ & $\%$ \\
\hline Professional & 23 & 6 & 5 & 7 & 4 & 13 \\
\hline White Collar & 118 & 30 & 19 & 28 & 10 & 33 \\
\hline Skilled Worker & 75 & 19 & 11 & 16 & 3 & 10 \\
\hline Unskilled Worker & 11 & 3 & 4 & 6 & 1 & 3 \\
\hline Housewife & 58 & 15 & 10 & 15 & 3 & 10 \\
\hline Student & 48 & 12 & 9 & 13 & 8 & 27 \\
\hline Retired & 49 & 12 & 8 & 12 & 0 & 0 \\
\hline Unemployed & 11 & 3 & 2 & 3 & 1 & 3 \\
\hline \multirow[t]{2}{*}{ Unanswered } & 6 & 1 & 0 & 0 & 0 & 0 \\
\hline & 399 & 101 & 68 & 100 & 30 & 100 \\
\hline Social Class* & $\mathbf{N}$ & $\%$ & $\mathbf{N}$ & $\%$ & $\mathbf{N}$ & $\%$ \\
\hline$\overline{\text { Upper Middle }}$ & 23 & 10 & 5 & 13 & 4 & 22 \\
\hline Lower Middle & 118 & 52 & 19 & 49 & 10 & 56 \\
\hline Upper Lower & 75 & 33 & 11 & 28 & 3 & 17 \\
\hline \multirow[t]{2}{*}{ Lower Lower } & 11 & 5 & 4 & 10 & 1 & 6 \\
\hline & 227 & 100 & 39 & 100 & 18 & 101 \\
\hline Age & $N$ & $\%$ & $\mathrm{~N}$ & $\%$ & $\mathbf{N}$ & $\%$ \\
\hline$\overline{11-30}$ & 117 & 29 & 20 & 29 & 13 & 43 \\
\hline $31-50$ & 117 & 29 & 20 & 29 & 9 & 30 \\
\hline \multirow[t]{2}{*}{$51+$} & 165 & 41 & 28 & 41 & 8 & 27 \\
\hline & 399 & 99 & 68 & 99 & 30 & 100 \\
\hline Sex & $N$ & $\%$ & $\mathbf{N}$ & $\%$ & $\mathbf{N}$ & $\%$ \\
\hline$\overline{\text { Male }}$ & 250 & 63 & 41 & 60 & 21 & 70 \\
\hline \multirow[t]{2}{*}{ Female } & 149 & 37 & 27 & 40 & 0 & 30 \\
\hline & 399 & 100 & 68 & 100 & 30 & 100 \\
\hline Marital Status & $\mathbf{N}$ & $\%$ & $\mathbf{N}$ & $\%$ & $\mathbf{N}$ & $\%$ \\
\hline Single & 151 & 38 & 28 & 41 & 11 & 36 \\
\hline Married & 178 & 45 & 32 & 47 & 16 & 53 \\
\hline Divorced & 20 & 5 & 3 & 4 & 1 & 3 \\
\hline Separated & 8 & 2 & 2 & 3 & 2 & 7 \\
\hline \multirow[t]{2}{*}{ Widowed } & 42 & 10 & 3 & 4 & 0 & 0 \\
\hline & 399 & 100 & 68 & 99 & 30 & 99 \\
\hline
\end{tabular}

* Only employed persons are used to compute social class. 


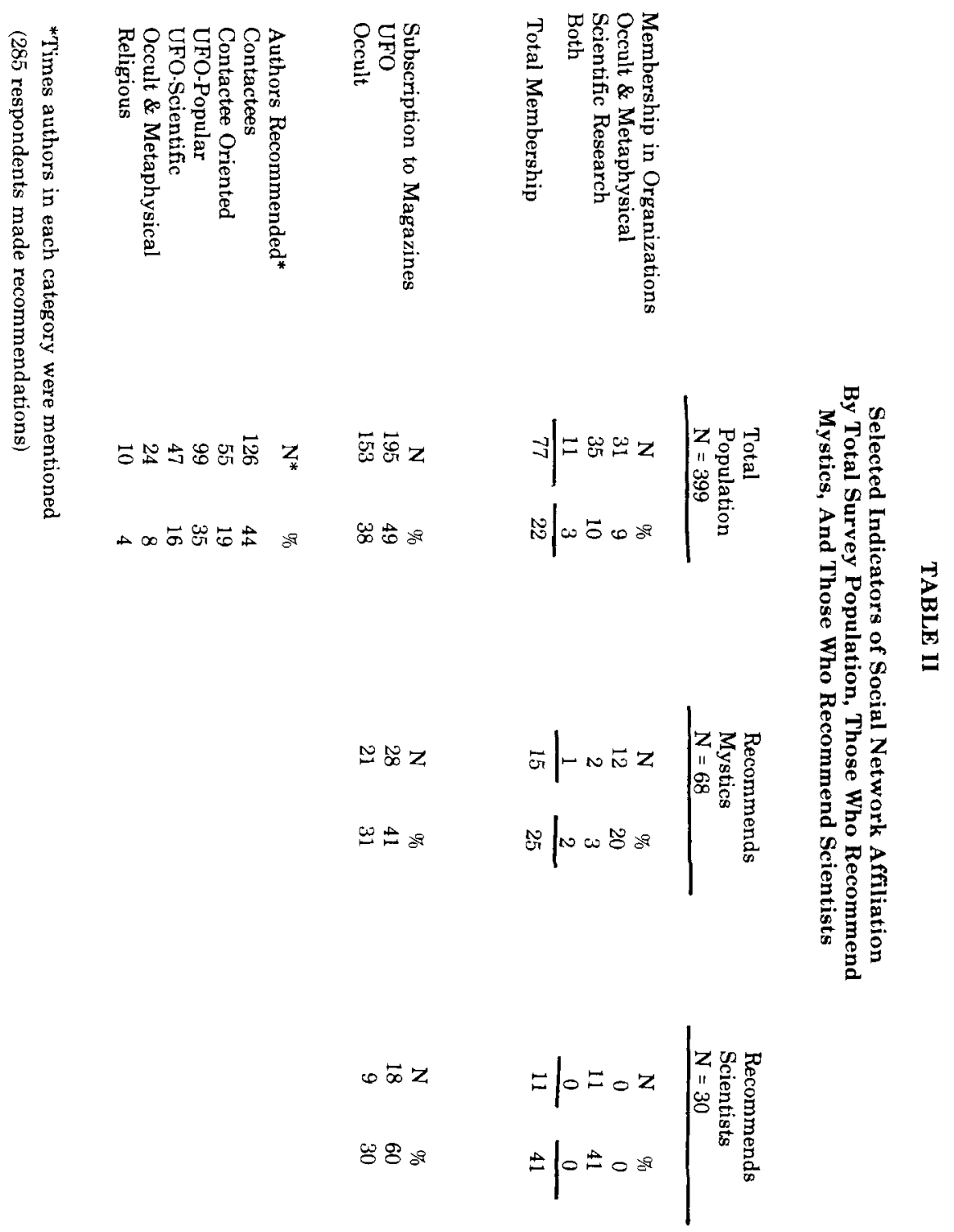


Table III illustrates what those interests and ideas are. In Holzner's terms, Table III presents the respondents' frame of reference. Consistent with the findings about the books recommended respondents rank contactee stories as the subject they most "want to see more books on." And if one reads down the list of recommended topics, it becomes clear that Saucerian Press readers have little interest in occultisms that are not directly associated with the flying saucer mystery. Four occultisms popular with the general public--Satanism, witchcraft, yoga, and astrology--are mentioned by only three to eleven percent of the research population. Furthermore, with the exception of lost continents and pyramidology, there is an inverse relationshp between topics of interest to Saucerian Press readers and those of interest to the general public. Several respondents wrote notes denouncing satanism and witchcraft. This suggests that the list of topics may perhaps be ranked according to their perceived sacredness and profanity.

Within the population of Saucerian Press readers the followers of the mystics have the greatest interest in the occult. Consider "The Great White Brotherhood." This is an alleged group of super beings introduced to the American public in the 1870 s by Madame Helena Blavatski, a co-founder of the Theosophical Society. ${ }^{9}$ Members of this superior race have reportedly broken the reincarnation cycle and live in remote mountain retreats, in invisible cities above the Earth's surface, on the moon, and on other planets. In Theosophical lore, some of these beings, known as Lords of the Flame, are visiting Earth where they are in contact with highly evolved Earthlings who they advise. ${ }^{10}$ Theosophy is the seedbed of many ideas developed by the flying saucer contactees, and the most successful flying saucer groups are basically Theosophical groups. The connection between Theosophy and the contactees shows up in Table III: forty percent of the followers of the mystics indicated interest in the Great White Brotherhood while twentyeight percent of the total population did so. Only seven percent of the followers of the scientists expressed similar interest.

The high interest in contactees among the followers of the scientists is not surprising. It reflects a new respect that has been developing since the publication in 1966 of journalist John Fuller's The Interrupted Journey, ${ }^{11}$ a best selling book that described the experiences of Betty and Barney Hill, a New Hampshire couple who, under hypnotic regression, related a story about being abducted and examined by aliens from space. The serious attention given to the Hills was followed by studies of hundreds of other alleged abduction and humanoid cases. ${ }^{12}$

Table III also shows that the followers of the scientists are disproportionally interested in the Men-In-Black. We know from participant observation that this is not merely an academic interest: some researchers have come to believe that there is a force that harasses researchers "who get too close to the truth." At one national meeting of the Mutual UFO Network, NBC Television was taping a segment for inclusion in their documentary "UFOs--Do you Believe?" Immediately after the 

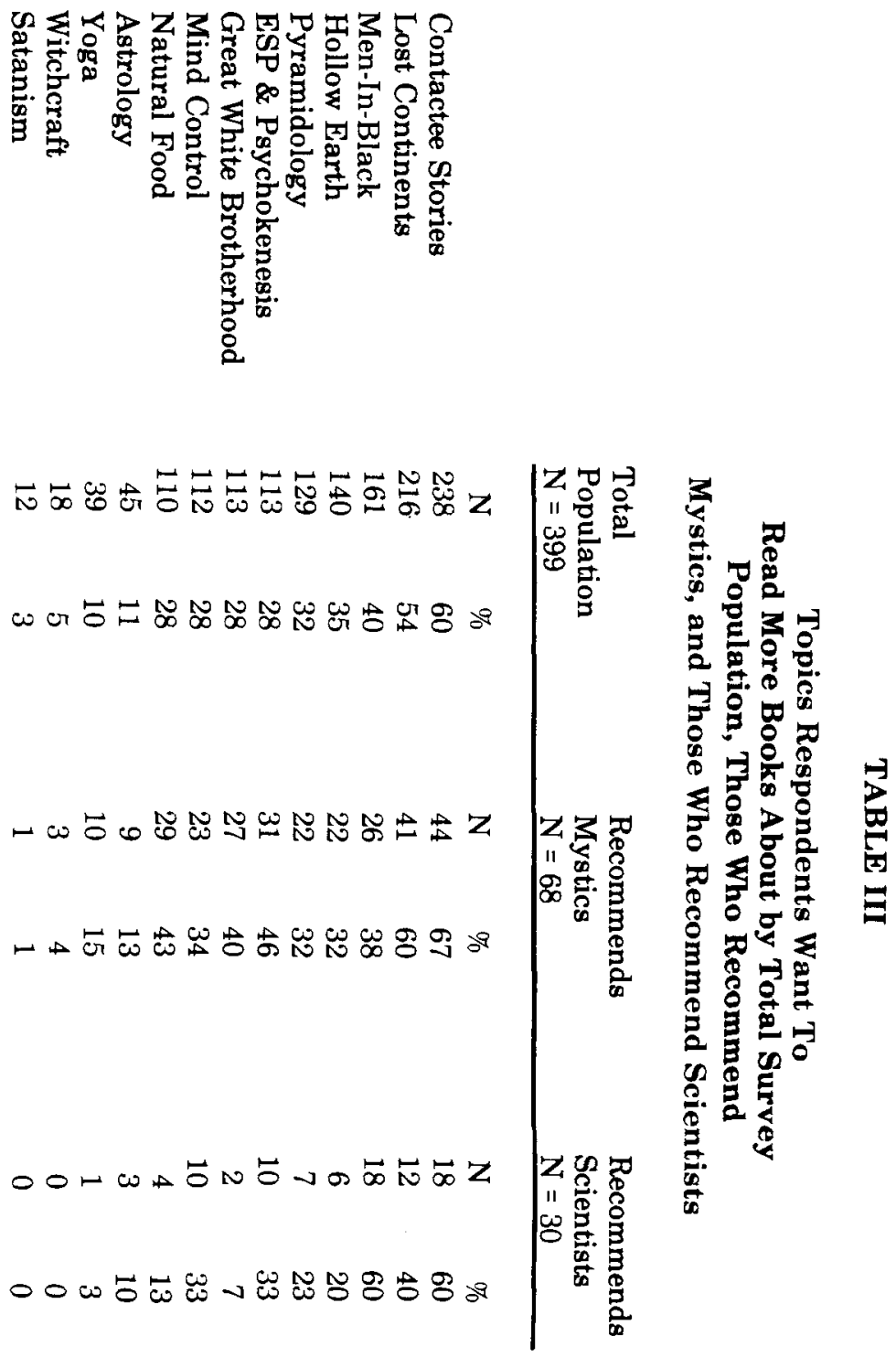
cameras were turned off, several participants, each from a different part of the country, excitedly and spontaneously revealed MIB stories. One man spoke of two strangers who came down in a helicopter, walked into his house, and took some papers that he had hidden. Similar events are common in the growing "MIB" folklore.

As Don Quixote invoked the presence of enchanters to reconcile discrepant experiences in his world of chivalry we may expect flying saucer hobbyists who adopt the flying saucer folklore as their paramount reality to believe in the functional equivalents of enchanters. The analog of friendly enchanters are the visiting spacemen (usually called spacebrothers)-physically, intellectually, and morally perfect beings who intervene in the affairs of men. A common claim is that, in the guise of hummanoids, they are working in the United States government. ${ }^{13}$ They are said to be able to avert wars, prevent natural disasters and heal the sick. Contactees, as the saucerers' apprentices, are reported to take on some of these powers. ${ }^{14}$

The Men-In-Black are the equivalent of evil enchanters. Usually understood to be from outerspace or from beneath the surface of the Earth, the MIB have also been linked in flying saucer folklore to conspiracies by international bankers and government agencies. MIB victims are said literally to die of fright. ${ }^{15}$

The father of this darker side of the flying saucer mystery is Ray Palmer, ${ }^{*}$ former science fiction writer and editor who in the 1940 s published allegedly true stories about degenerated races that launch spaceships from inside the Earth. One race, the Dero, is particularly malevolent:

"They exist in caves and many of our troubles are caused by them; our terrible air accidents are not accidents at all but the result of the destructive rays aimed at them by idiots whose only delight is death and torture. Even our nightmares are a result of their 'dream mech' trained on us in our sleep..."16

Today Palmer ranks with Barker as the dominant publishers of occultoriented flying saucer literature. ${ }^{17} \mathrm{He}$ has refined his Hollow Earth theory and has published photographs showing what he claims are "holes at the poles." Most recently he has published articles about the John Kennedy assassination "conspiracy" and a secret international political organization of super-rich conspirators known as the Bilderbergers. ${ }^{18}$

Saucerian Press readers obviously share Palmer and Barker's conspiratorial world-view. Table IV shows that ninety-two percent of the population believes in a government conspiracy. For followers of the mystics the percentage reaches ninety-seven percent while the followers of the scientists score somewhat lower. Belief in the Men-In-Balck (Table IV) provides more striking findings: while only forty-four percent of the total population holds this belief, eighty-six percent of the followers of the mystics and eighty-three percent of the followers of the scientists so believe.

Table IV indicates that the majority of the research population believes in the extraterrestrial explanation for the origin of UFOs. As the mystics 
TABLE IV

Various Beliefs by Total

Survey Population, Those Who

Recommend Mystics, and Those

Who Recommend Scientists

Government is Suppressing the Real Truth about UFOs ${ }^{1}$

Those who Believe that a "Silence Group" or Men'inBlack harasses UFO

Witnesses $^{2}$

Explanations for the Origin of UFOs:

Extraterrestrial

Fourth Dimension

Hollow Earth ${ }^{3}$

\begin{tabular}{lll}
$\begin{array}{l}\text { Total } \\
\text { Population }\end{array}$ & $\begin{array}{l}\text { Recommends } \\
\text { Mystics }\end{array}$ & $\begin{array}{l}\text { Recommends } \\
\text { Scientists }\end{array}$ \\
\hline $92 \%$ & $97 \%$ & $80 \%$
\end{tabular}

$44 \%$

$86 \%$

$83 \%$

$\begin{array}{lll}70 \% & 88 \% & 63 \% \\ 61 \% & 41 \% & 30 \% \\ 29 \% & 32 \% & 23 \%\end{array}$

1. $\mathrm{N}$ for total population $=341 . \mathrm{N}$ for recommends mystics $=66$. $\mathrm{N}$ for recommends scientists $=30$.

2. $\mathrm{N}$ for total population $=289 . \mathrm{N}$ for recommends mystics $=44$. $\mathrm{N}$ for recommends scientists $=25$.

3. $\mathrm{N}$ for total population $=399 . \mathrm{N}$ for recommends mystics $=68$. $\mathrm{N}$ for recommends scientists $=30$. Some respondents chose more than one explanation

Note: Some respondents did not answer the entire questionnaire. 
claimed contact with spacemen it is not surprising that their followers accept this explanation. Members of scientific research organizations, traditionally disassociating themselves from the occult, have accepted the extraterrestrial explanation as an article of faith. ${ }^{19}$

The fourth dimension explanation, the idea that entities exist unseen in a fourth dimension making themselves visible at will, is a Theosophical idea that has been adopted by some contactees and their followers to explain discrepant events. Flying saucers, for instance, reportedly have the ability to go through the color spctrum and then disappear. How, the skeptic asks, is this possible? The answer, according to the believer, is that they go to another "dimension." And why didn't the astronauts see spacemen on the moon? "Well," comes the reply, "they were vibrating at another level of existence." Recently (and for the most part after this survey was conducted) the fourth dimension explanation has become popular with certain researchers, some of whom have argued that intraterrestrial beings may be purposefully misleading the contactees to make them look foolish, thus discrediting all UFOlogy. ${ }^{20}$ Table IV shows that while most of the Saucerian Press respondents accept the fourth dimension explanation, the acceptance level among both the followers of the mystics and of the scientists is relatively low. We would expect that a future survey of Saucerian Press readers would show a higher level of acceptance by these two audiences.

The Hollow Earth theory ranks a solid third among explanations in popularity, but since most people would probably consider this by far the most bizarre of the three explanations, the real surprise is that it is as popular as it is. The fact that twenty nine percent of the population takes such an idea seriously suggests that there are respondents who take the flying saucer folklore to be their paramount reality. And the fact that the "Hollow Earth" has been linked with evil also is consistent with the religious world view that appears to be the rule in this community of believers. You can't have a Heaven without a Hell.

We now turn to the question of reality tests. Do survey respondents have psychic experiences that validate their beliefs? The answer (see Table V) seems to depend on the orientation of the respondents. Of the followers of the mystics who answered the question "Have you had any unusual psychic experiences," seventy-nine percent said "yes." That positive response rate drops off sharply to only fifty-five percent for the respondents as a whole and forty-eight percent for the followers of the scientists. These figures may be underrepresentations because among those who did not answer the question "yes" are several persons who replied that they had no unusual psychic experiences. Also, forty-six respondents reported having psychic experiences but failed to describe them.

Table $\mathrm{V}$ provides a breakdown of described experiences. Topics related directly or indirectly to UFOs rank high: thirty-four percent of the population reported UFO. Colaterally, apparitions and out-of-body experiences are phenomena commonly claimed by contactees. Topics that 
Table V

Psychic Experiences by Total Survey

Population, Those Who Recommend

Mystics, and Those Who Recommend Scientists

\begin{tabular}{llll} 
& $\begin{array}{l}\text { Total } \\
\text { Population* }\end{array}$ & $\begin{array}{l}\text { Recommends } \\
\text { Mystics* }^{*}\end{array}$ & $\begin{array}{l}\text { Recommends } \\
\text { Scientists* }\end{array}$ \\
\cline { 2 - 4 } Had Psychic Experience & $55 \%$ & $79 \%$ & $48 \%$ \\
Described Psychic Experience & $41 \%$ & $62 \%$ & $41 \%$ \\
Incidence of type of & & & \\
experience described: & & & \\
UFO Sighting & $14(34)^{* *}$ & $24(31)^{* *}$ & $10(25)^{* *}$ \\
Premonition & $11(28)$ & $14(19)$ & $7(17)$ \\
Apparition & $6(16)$ & $7(9)$ & $7(17)$ \\
Out-of-body & $5(12)$ & $7(9)$ & $17(42)$ \\
Contact with UFO & $5(12)$ & $7(9)$ & $7(17)$ \\
Telepathy & $4(10)$ & $17(22)$ & $0(0)$ \\
Poltergeist & $3(8)$ & $2(3)$ & $3(8)$ \\
Reincarnation & $3(7)$ & $5(6)$ & $3(8)$ \\
Religious & $3(6)$ & $0(0)$ & $0(0)$ \\
Clairvoyance & $2(5)$ & $2(3)$ & $3(8)$ \\
Communication with & & & $3(8)$ \\
Dead & $1(2)$ & $0(0)$ &
\end{tabular}

*316 respondent answered this part of the questionnaire. 53 respondents who recommended mystics answered this part of the questionnaire. 29 respondents who recommend scientists answered this part of the questionnaire.

**The absolute number of respondents who described their experiences were: 129 of the total population, 32 who recommend mystics, and 12 who recommend scientists. Percent of type of described experience shown in parenthesis. Note: some respondents described more than one type of experience. 
rank low in frequency--poltergeist, reincarnation, religious experience, clairvoyance, and communication with the dead--are related to UFOs or not related at all. Thus, just as Saucerian Press readers do not express a great interest in reading more about non-UFO occultisms (see Table III), they generally do not experience or report non-UFO occultisms as psychic events.

\section{Conclusions}

In contrast to UFO cults where members invariably are socially and intellectually part of a larger occult social world, the customers of the Saucerian Press (1) belong to few occult groups interested in UFOs (2) are interested in few occultisms that are not related to UFOs, and (3) experience relatively few psychic events that are unrelated to UFOs. On the other hand they (1) exhibit a great interest in contactees and concepts directly related to the folklore about contactees, (2) recommend books by and about contactees and want to read more about them, and (3) share the conspiratorial world views explicit in the contactee folklore. The Saucerian Press readership, in a phrase, is a world apart from the members of flying saucer cults. They are a mass, bound not together, but to a common source of information.

But, the question remains, are they part of an epistemic community? An ideal-typical epistemic community would have mechanisms for constructing, expanding, and testing knowledge, and mechanisms for distributing and controlling the orientations of its members. Let us analyze these considerations in order.

Barker's Saucerian Press and Palmer's Amherst Press, together with allied small publishing houses, are adequate mechanisms for construction and expanding reality systems, but to test the knowledge readers must have confirming personal experiences. The data on psychic experiences indicated that only a small minority of respondents has had a UFO-related experience that might count as a reality test; almost half of the respondents, in fact, report no psychic experiences at all.

The problem of distributing and controlling orientations is more telling. The data, particularly on employment and marriage, suggest that the readership is at least reasonably integrated into the world at large and since the respondents presumably have little interaction with each other, the chance for mutually re-inforcing this world-view is limited. Clearly the orientations of the readership of the Saucerian Press are not controlled in the sense that Holzner had in mind.

For all but perhaps a few cases, the flying saucer folklore appears to be, at most, a diversion-in theoretical terms, a subuniverse of experience. For it to be a paramount reality would require the presence an organization with the capacity to provide a more total life experience to its followers. 


\section{NOTES}

${ }^{1}$ We use the term folklore in the most inclusive sense. See Alan Dundes, The Study of Folklore. Englewood Cliffs, N.J.: Prentice-Hall, 1965, pp. 1-4. Recent in origin and still in the process of development, flying saucer folklore consists of a body of concepts and legends that are transmitted both orally and by newsletters and books.

${ }^{2}$ Gray Barker, They Know Too Much About Flying Saucers. New York: University Books, 1956.

${ }^{3}$ Reprinted in William James, The Essential Writings. New York: Harper and Row, 1971, pp. 132-145.

${ }^{4}$ See Alfred Schutz, Collected Papers, Volume II. The Hague: Martinus Nijohoff, 1964, pp. 135-148.

${ }^{5}$ We have selectively adapted and simplified portions of Holzner's complex theory. See Burkart Holzner, Reality Construction in Society. Cambridge, Mass.: Schenkman Publishing Co. Inc., 1967.

${ }^{6}$ See John C. McKinney, Constructive Typology and Social Theory. New York: Appleton-Century-Crofts, 1966.

7To establish firmly the extent that Saucerian Press readers are integrated into the larger society would call for more detailed data, preferably from interviews. It would also be helpful to comapre these data with a control group. With these limitations in mind, we still conclude that the data do not support the popular image of flying saucer enthusiasts as "little old ladies in tennis shoes." This conclusion is consistent with our field work observation that believers in flying saucer contactees are generally ordinary people with ordinary lives who have some extraordinary beliefs.

${ }^{8}$ The distinction commonly made is that a mass is a fragmented collectivity of people oriented to a common source and a public is an organized group of people who interact with each other. See Ralph Turner and Lewis Killian, Collective Behavior. Englewood Cliffs, N.J.: PrenticeHall, 1972.

groups see J. Stillson Judah, The History and Philosophy of the Metaphysical Movements in America. Philadelphia: The Westminister Press, 1967.

${ }^{10} \mathrm{~A}$ concise presentation of the Theosophical cosmology is available in C.W. Leadbetter, A Textbook of Theosophy. Adyar, Madras, India: The Theosophical Publishing House, 1956. (First edition, 1912).

${ }^{11}$ John G. Fuller, The Interrupted Journey: Two Lost Hours "Aboard A Flying Saucer." New York: The Dial Press, 1966.

${ }^{12}$ See Charles Bowen (ed.), The Humanoids. London: Neville Spearman, 1969; and David Webb, 1973-The Year of the Humanoids. Evanston, Ill.: Center for UFO Studies, 1976.

${ }^{13}$ A classic example of this claim may be found in Frank Stranges, $M y$ Friend from Beyond Earth. Kitchner, Ontario: Galaxy Press, 1972.

${ }^{14}$ See, for instance, Ted Owens, How to Contact Space People. 
Clarksburg W. Va.: Saucernan Press, 1969; and Michael X. Venusian Health Magic. Clarksburg W. VA.: Saucerian Press, 1972.

${ }^{15}$ A discussion of MIB Stories is available in John Keel, Our Haunted Planet. Greewich, Conn.: Fawcett Publications, 1971.

${ }^{16}$ Ray Palmer, The Hidden World, A-112 (Spring, 1961)

${ }^{17}$ Barker and Palmer have no competitors of consequence although the Galaxy Press, a one-man operation in Kitchner, Ontario has had some success publishing uncopyrighted pamphlet length books by little known contactees. Some respondents report that they also read popular newsstand magazines like Official UFO, UFO Report, and Saga. These magazines are written for the reader with a casual interest in UFOs who is unaware of the elaborate belief system created by Barker, Palmer and others.

${ }^{18}$ Ray Palmer, Forum, 10:10-21 (July, 1975).

${ }^{19}$ See Michael K. Schutz, "Organizational Goals and Support-Seeking Behavior: A Comparative Study of Social Movement Organizations In The UFO (Flying Saucer) Field." Unpublished PH.D. dissertaion. Northwestern University, June, 1973.

${ }^{20}$ Variations of this theme may be found in the work of Jacques Vallee, John Keel, and Brad Steiger. See Jacques Vallee, The Invisible College. New York: E.P. Dutton, 1975; and John A. Keel, The Eighth Tower. New York: E.P. Dutton and Co., 1975; and Brad Steiger, Revelation: The Devine Fire. Englewood Cliffs, N.J.: Prentice-Hall, 1973. Also of interest is the theory of chemical engineer Leon Davidson who argued that the Central Intelligence Agency has been systematically responsible for hoaxing and encouraging the contactees. Davidson's statement and replies are available in James Moseley, Jim Moseley's Book of Saucer News. Clarksburg, W. Va. Saucerian Press, 1967. 